\title{
Creating Buzz by Using Media to Make School Gardens Communication Happen
}

\author{
Hara Giannakopoulou ${ }^{1}$, Constantina Skanavis ${ }^{2}$ \\ ${ }^{1}$ Junior Researcher at University of Aegean, Department of Environment, Environmental Education and \\ Communication Research Unit, University of the Aegean, Greece \\ ${ }^{2}$ Constantina Skanavis, Professor in Environmental Education and Communication, Department of Environment, \\ University of the Aegean, Greece \\ Correspondence: Constantina Skanavis, Professor in Environmental Education and Communication, Department of \\ Environment, University of the Aegean, Greece
}

Received: June 23, 2014 Accepted: July 9, 2014 Available online: September 22, 2014

doi:10.11114/smc.v2i2.448

URL: http://dx.doi.org/10.11114/smc.v2i2.448

\begin{abstract}
This study focuses on the Greek media's active involvement and comprehension of the environmental education area, paying special attention to school gardens. The infiltration of gardens in Greek schools is still in the early stages, due to limited infrastructure. A small portion of the Greek society is aware of their existence and the associated benefits of school gardens to the promotion of a quality everyday life. The importance of the environmental maintenance is heavily stressed, giving examples of human environmental activities that need to be publicized and replicated. The history behind the school gardens' movement is presented as well as their multilevel significance in a holistic education for youth everywhere. The role of media around the globe on the promotion of health, nutrition and wellbeing in general, is emphasized. The analysis of this study's results, points out the need for Greek journalists to invest further in the shaping of responsible environmental behavior. Media should also support environmental education activities, which take place in the Greek schools, by making them publically known. School gardens present an excellent case scenario for media's pro environmental share of responsibility.
\end{abstract}

Keywords: school gardens, environmental education, media, environmental behavior

\section{Introduction}

Sense of place fosters an individual's willingness to engage in environmental stewardship (Chapin et al., 2011) and contributes to pro-environmental behaviors or intentions (Halpenny, 2010; Scannell and Gifford, 2010). Based on that, scholars propose that sense of place could be purposely influenced in order to promote pro-environmental behavior (Walker and Chapman, 2003).

Leopold's (1949) suggestion that landscapes include multiple aspects such as ethical, esthetic, economic, and ecological resembles the current idea of multiple dimensions of place meanings. Firey (1945) recognized that people ascribe symbols to places based on cultural values and historical associations, and these symbols may influence land use. Lynch (1960) was one of the first to use the term "sense of place," referring to symbolic and memorable aspects of the urban environment. In the 1970s, Tuan (1977) developed an experiential perspective on sense of place, which in his view is created through personal experiences with physical settings, and which can be understood through holistic studies of lived experiences and Relph (1976) distinguished such aspects of sense of place as place attachment and place meaning. In his view, place attachment represents ties between people and places, and place meaning is the essence of places or symbolic associations of places that define people's individual and cultural identity. Sense of place is what people seek when gardening, and when they are asked about their gardening experience, they respond that it is about a relationship with place, plants and other people. Obviously gardens contribute more than just working on open spaces (Tidball and Krasny, 2009). Furthermore it is possible that some cultural, social, and other place meanings do impact the ways people influence their places and more broadly their environment (Jacobs and Buijs, 2011). Place attachment reflects how strongly people gravitate towards places, while place meaning describes the reason for place attachment (Stedman, 2008).

Community gardens provide opportunities for social interaction, through shared enjoyment of gardening (Schrieber, 
1998). The emergence of community gardening in modern US history is often attributed to World War I. However, the original movement began in the 1890s. As a result of the social, environmental, and economic climates of the time, school gardens and vacant-lot cultivation projects began to take form in an effort to address urban congestion, immigration, economic instability, and environmental degradation of the late 19th century (Lawson, 2005). School gardening in the United States was originally introduced for aesthetic purposes. It waned in the 1950s because of the nation's focus on technology (Subramaniam, 2002).

A garden can serve as a dynamic resource for scientific observations and outdoor investigations which was underlined by both Froebel (1782-1852) and Montessori (1870-1952). The idea of a school garden as a laboratory for science education was put into practice in 1978 at the Green Acres Elementary School in Santa Cruz, California. The "Life Lab" idea, which basically was a hands-on, garden-centered science curriculum experience, that links the lessons of the garden to other domains of learning, especially language acquisition, nutrition and environmental stewardship. By the early 21st century, over 1000 schools around the nation had formally adopted the Life Lab curriculum, and countless others had informally modeled their own school gardens on this model. In earlier eras, Rousseau, Gandhi, Montessori, and Dewey-most notably- promoted school gardens. The goal of school gardens was to teach through experience, to connect children to pastoral nature, and to shape their moral outlook (Subramaniam, 2002). School gardens and city garden plots at the turn of the twentieth century, typically were organized by upper and middle class reformers to achieve the moral, cultural and esthetic uplift of poor and working class people, many of them foreign born immigrants and their children, who were becoming a ubiquitous presence in urban areas and, in the eyes of reformers, a threat to social order and national identity(Bassett, 1979). In the recent years, motivated by her two young daughters and the desire to instill in them a love for eating fresh fruits and vegetables, First Lady Michelle Obama broke ground on a garden located at the White House, in 2009 and launched a school garden movement in USA.

Gardens that children help to plan allow close, personal experiences with the earth, repeated sensory contact, and interaction with a particular intimately known space, creating confidence in the processes of nature that some researchers believe is necessary for healthy human development (Thorp \& Townsend, 2001). Evaluating the effect of children's gardens on children in terms of development of pro-environmental behavior would give children's gardens a position in relation to the field of environmental education. To live sustainably, individuals must understand that their actions affect the environment. Schools have a major role in this process and teachers' pedagogical approaches to Environmental Sustainability Development need to prepare all children to think about their actions in everyday life. Lessons out-of-doors in a garden introduce children to hands-on experience, observation of natural processes, changes over time and overarching realities. Skills taught in schools need to prepare children for a world in which there may be a scramble for food in a crisis or if disease crosses international borders, and mainly to support children to avert the devastation of biodiversity and halt financial gain from degrading the environment unopposed (Brundtland, 1987). Finally, developing ecological place meaning could redefine self-identity of urban residents, and influence their pro-environmental behavior (Whitmarsh and O'Neill, 2010).

There is ongoing media attention about the current and future fragile state of the environment and adults are concerned for the ecological future of the planet if children grow up not caring about or fearing nature (Kong, 2000). The media are considered to be a powerful disseminator of information to the public because of its potentially vast audience. Increasingly, there is a realization that media messages have the potential to, not only educate, but to motivate people to change attitudes. Technology sources (Hastings \& Tracey, 2005) including mass media delivered through television, movies and print have not only entertained, but also have served as a source of education within the United States for several decades (Hertzler, 1990). Educational films have been shown to increase retention of knowledge (Williams et al., 1980) and computer-assisted nutrition instruction has been implemented in over 70 medical schools in the U.S. (Cooksey et al., 2000). This power that the media wields, especially in terms of health promotion, should not be underestimated since its effect goes far beyond information-dissemination, or simply the reporting of the news. Media messages serve to not only educate individuals with factual information, but to promote attitude, behavior, and even public policy changes (Heneghan et al., 2007). Because of this, the news media is actively used as a medium for health advocacy groups, research institutions and publications that publish peer-reviewed research to relay public-health messages.

The media are considered to be a powerful disseminator of information to the public because of its potentially vast audience. Media messages have the potential, to not only educate, but to motivate people to change attitudes. The news media is actively used as a medium for health advocacy groups, research institutions and publications that publish peer-reviewed research to relay public-health messages. "Giving the public comprehensible and useful information on the relationships between diet and health is a major component of public health efforts to promote healthful dietary patterns" (Patterson et al., 2001). Campos et al., (2006) suggest that "the exponential increase in mass-media attention to obesity" that defines obesity as a disease and treats "the population's weight gain as an impending disaster" may be 
contributing to changing attitudes or beliefs by creating a "moral panic" that may be encouraging discrimination against minorities and the poor who have higher rates of obesity. The implications of the high rates of childhood obesity have been at the forefront of the public health agenda, so the media attention may be a reflection of this. Among health, nutrition and physical-activity educators, it is widely acknowledged that since the media pays such a potentially powerful role in providing information (Bartlett, Steme, and Egger, 2002; Calloway et al., 2006), shaping attitudes (O'Hara \& Smith, 2007) and triggering behavior change (Goldberg, 1992; Oxman et al.,1993), it is important to understand the messages being conveyed (Keenan et al., 2001).

With school gardening as a central tenet of a curriculum, place-based learning can shape values and behaviour and examine attitudes to sustainable living. Lessons out-of-doors in a garden introduce children to hands-on experience, observation of natural processes, changes over time and overarching realities. Actions taken in a school garden are given a purpose and children have the opportunity to develop not only gardening skills, but also higher order thinking as they design small-scale experiments, explore natural cycles and challenge the beliefs and values of others. There is the potential for progression from the personal to the civic or global dimensions for all age and ability groups. Moving through the levels and linking chains of experience, many children make small contributions to the whole school's action competence. Individuals learn to co-operate and collaborate with their peers and make democratic decisions as they organize the garden and workload. Also, a school garden can become a familiar place which throws up constant surprises and hindrances that intrigue children. Individual children may prefer to take on specialized responsibilities which bring 'self-efficacy' (Bandura 1997), but they also have to co-operate with others to reach a goal. Although school gardens may be part of a systemic response to the United States obesity crisis, it is important that inquiry on school gardens extend beyond nutrition to the potential effects of the psychosocial and academic development of youth and on the school as a setting for development.

Until today, there are no studies focused on the role of the Greek media towards environmental education. This research studies what Greek journalists know regarding environmental education and more specifically about school gardens. Also, it tries to focus on what the journalists know regarding the contribution of the international media on environmental issues. Furthermore, this research records the intention to cover this type of issues by the greek media as well as the way Greek journalists have dealt with these particular issues so far.

\section{School Gardens}

Place meaning is a multidimensional symbolic construct and may reflect various settings related to people's perspectives on environment, social interactions, culture, politics, economics, and esthetic aspects (Ardoin 2006; Young 1999a), as well as reinforcing or contradicting personal experiences (Kong and Yeoh, 1995). It is possible that based on cultural, social, and other place meanings, the ways people impact their places and the environment, are substantially being influenced (Jacobs and Buijs, 2011), and hopefully their pro environmental behavior is being influenced. Chapin et al. (2011) suggest that sense of place, predetermines an individual's willingness, to actively participate in environmental decision making. Gardening connects people to a specific place, the plants and other people (Tidball and Krasny, 2009). Bonding to places can inspire action, because people are motivated to seek, stay in, protect, and improve places that have somehow affected them (Brown and Perkins, 1992). The gardens obviously present opportunities to engage in social skills, like behaving manners and relations with other people, building friendships and affections, self-confidence, and working etiquettes. Gardening heals the spirit and body, expands the mind, and realizes human need for connection with the earth and society. In this fast pace and quite artificial world, Kellert (2002) states that, nature remains an inspiration source of attraction, stimulation, and challenge relevant in youth's intellectual and emotional development.

Community gardens enhance positive dietary habits and preference, such as increased fruit and vegetable consumption, regardless of setting or population characteristics (Aliamo et al., 2008; D’Abundo \& Carden, 2008; Heim et al., 2009; Hermann et al., 2006). During the 1980s, community gardens, sparkled empowerment and community organization (Kweon et al., 1998; Kuo and Sullivan, 1998).

Recently, gardening has regained its beneficial reputation for children (Wake, 2008; Blair, 2009). In school education, the garden has been recognized as a multidimensional learning environment. Multiple advantages related to social aspects, like improved attitudes towards school and community, sense of ownership and pride and increased learning outcomes, have been attributed to gardening (Rahm, 2002; Blair, 2009; Passy et al., 2010). Literature has reported the value of gardens in establishing a close relationship with nature and sustainability, through development of environment-friendly attitudes and behavior among the participating children (Chawla, 2007; Gross and Lane, 2007). Children's gardens and gardening programs have been assessed to be benefit the physical, psychological, educational and social dimensions of children (Chawla, 1994; Hart, 1994; Louv, 2005; Ozer, 2007). Just because, learning takes place through play and fun (Montessori, 1964), children's gardens, should not be perceived as playgrounds. They are 
intended to provide environmental experiences and learning opportunities through planting for children, who in our days are alienated from nature (Wake, 2007a). Within gardens children while connecting with the natural environment from a multi-disciplinary perspective they can affect their learning in areas such as science, math, horticulture, ecology, geography, art, drama, teamwork and communication (Miller, 2007; Taylor, 2000). In the state of New York, school gardens have been greatly implemented, with more than 200 schools, 100 teachers, and 11,000 students garden using a state curriculum (Faddegon, 2005). School gardening covers a variety of activities in an effort to deal with the horticultural complexity of the schoolyard. Therefore potted plants, raised beds on asphalt, composting in-ground plantings (Graham et al., 2005), habitat and butterfly gardens, sunflower houses and ponds, and a systematic approach to redesign the outdoor space around schools into learning landscapes (Brink and Yoast, 2004) are some of the experienced approaches. The driving purposes behind this schoolyard redesigning movement are academic, behavioral, recreational, social, political, and environmental. The children's garden movement has underlined the need for healthy living for children through exercise, exposure to nature and healthy lifestyle (Miller, 2005; Ozer, 2007). Other benefits of school gardens have been potential reduction attention-deficit/hyperactivity disorders and juvenile delinquency (Kuo and Faber Taylor, 2004). Classroom education gets, significantly enriched by students' personal experiences and observation of nature (Nabhan and Trimble, 1994). Gardening brings the individual in direct contact with nature which in reality is a miniature environment (Demas, 1979). Gardens introduce children to simple as well complex situations like growth and decay, predator-prey relations, pollination, carbon cycles, soil morphology, and microbial life. In their research, Dyment and Bell (2007) also found that children preferred to garden in school gardens, rather than simply visit them. Experiencing nature in a holistic and hands on manner is known to have a strong impact on children's developmental areas like the cognitive, affective, and value-related ones (Kellert, 2002). It should though be stressed that both Nature and natural are terms that relate to each other but they also depend on cultural characteristics and the past experience with place (Finch, 2004; Mergen, 2003). Finally it has been described that the specific learning style experienced in school gardens, using direct contact with natural phenomena, is considered experiential, inquiry-based learning grounded in concrete experience (Corson, 2003; Kellert, 2002; Rahm, 2002). Kellert (2002) underlined the fact that the rapid change of nature is the fact that attracts and stimulates a child's attention. In recent decades gardens (Waliczek et al., 2000) and gardening curricula predominantly have been targeting elementary students.

Today's young children have been overwhelmed with television, video games, and organized sports and lack experience with natural ecosystem complexity. Unsupervised wandering and environmental exploration have become almost obsolete activities (Moore, 1995) and the intimate spaces grounded in the natural environment have almost vanished (Francis, 1995). Many authors and researchers believe that today's children lack the exposure to the natural world that shapes environmental values and puts science in context (Finch, 2004; Orr, 2002). Chawla (1998) found that adults who had significant and positive exposure and experiences to nature as children were more likely to be environmentally sensitive, concerned, and active. Kong (2000) shares adults' environmental concern if children grow up not caring about or fearing nature. Media alert people that we are doomed if environmental protection is not enforced. Research by Barratt Hacking et al. (2007) indicates that children are interested in and concerned about the state of the environment, although they engage with the environment differently to adults. Children's typical behaviors are imaginative exploration and manipulation of the environment (Heerwagen and Orians, 2002). The teacher and principal are major variables in school-garden success. Support may come in the form of (a) enthusiastic principals, (b) effective and credible lead teachers who promote school gardening through contagious student excitement rather than through personal power (Vesilind and Jones, 1998). School-gardening experience and plant science could become a part of teachers' pre-service education, so that all teachers can feel prepared to use school gardening as a potent form of experiential education.

\section{Media and Behavior}

Mass media is an enormous profitable social entity. The media are a powerful disseminator of information to the public because of its potentially vast audience. One issue of a newspaper or magazine can be "circulated" (sold, or distributed at no cost), to hundreds of thousands to millions of people and can be read, by more than one person, further increasing the exposure of an issue. Individuals obtain information and guidance on nutrition and fitness from a variety of mass media sources (Contento, 2007). The media are consistently ranked, by the public as a main, or even primary, source of nutrition and health information (Basu and Hogard, 2008; Borra et al., 1998). Media messages have the potential to educate as well as motivate people to change attitudes and shape beliefs about the world in which we live (Bell et al., 2005). Media coverage has even been correlated with adult quitting behavior (Pierce and Gilpin, 2001). Public health messages are relayed through the media based on the assumption that media messages have the potential to result in positive behavior (Heneghan et al., 2007) and public policy changes (Holder and Treno, 1997), with the most powerful example being the decline in smoking rates and changes in public-smoking policies that emerged after many years of media reports publicizing the dangers of both smoking and passive-smoke exposure (Kennedy and Bero, 1999). 
The media exert influence through what has been proposed as their agenda-setting function, though which they selectivity choose which topics to cover (Neuendorf, 2002). Once awareness is raised towards those specific issues, they are then perceived by individuals and the public to be important ones and therefore they affect attitudes and behavior. Media can also minimize importance of issues by choosing not to cover some of them (Caburnay et al., 2003). Giving the public comprehensible and useful information on the relationships between diet and health is a major component of public health efforts to promote healthful dietary patterns (Patterson et al., 2001). Research indicates food selection of both children and adults can be influenced by what was viewed from mass media advertising (Gore et al., 2003; McNeal, 1992). People in the United States are saturated with mass media nutritional messages from television and print. Children aged 2-12 and adolescents aged 13-18 report viewing over 4,000 to 6,000 food-related advertisements each year, respectfully, (Gantz, 2007) and fifty percent of all advertisements children see contain nutrition-related messages (Taras and Gage, 1995). On the other hand, educational films have been shown to increase retention of knowledge (Williams et al., 1980). Therefore, gaining nutritional education was not limited to just school. Awareness raising may bring brand-new issues to an individual's and the public's consciousness, or may in advertently increase the perception of importance to already-known issues (Caburnay et al., 2003).

A correlation between watching television and obesity in children and adults exists (Jeffery and French, 1998; Robinson, 1999). Television advertisements predominantly show messages containing snacks with high energy and low nutrient density (Kuribayashi et al., 2001). Seventy-percent of television advertisements viewed by children during peak viewing times contained messages of foods with high amounts of fat and sugar and no fruits or vegetables (CWS, 2000). Twenty-five percent of primetime and weekend daytime commercials contained "junk" food messages (Gerbner et al., 1981). On average, food was found to be referenced two to three times during a 30 minutes television programming segments (Kaufman, 1980) with most references geared towards unhealthy dietary choices (Bell et al., 2009; Parvanta et al., 2008). Due to the resulted alarming children's obesity rates, First Lady Michelle Obama created an initiative to decrease the incidence of obesity within one generation (DHHS, 2010). The platform, -Let's Move 2010l, puts emphasis on physical activity, food quality in schools, meal programs and most importantly, nutrition education within the public K-12 school system, which shows that media and public figures can make a real difference on issues that have to do with promotion of quality everyday life.

In Greece there is no specific specialization of journalists on the different media disciplines (environment, finance, social, politics etc.), while most of the journalists have no journalism studies on their educational background. As a result, it has been observed that the greatest percentage of Greek journalists will deal with issues that are of the greatest interest for the audience at the given time (regardless their specialization or personal interest). This fact is observed more in younger journalists, since they believe that this way they will earn professional recognition faster.

\section{Research}

The research took place in Greece. In this research, 14 Greek journalists were chosen, who have shown increased environmental interest through their work, and who have Mass Media studies on their educational background, before starting working as journalists. Interviews were used as the applied research tool, where through specially formatted questions, the ultimate objective was to study the view of respondents for the issue of school gardens. First, they were asked some demographic/social questions, such as their age, gender, family status, education, employment, and their current professional status, as well as how many years they are practicing the profession of journalism. Then there were some questions relating to environmental education and the existence of school gardens both in Greek schools and abroad. More specifically, there were questions about journalists' knowledge about environmental education, school gardens and their perceptions on the associated benefits. Also, they were asked on how much they are informed about Michelle Obama's work on school gardens' movement. Questions, regarding the existence of school gardens and related environmental actions in Greek schools were administered. The journalists were asked about media's contribution to the school gardens' promotion in Greece and elsewhere and what is the reason and way of approach when they disseminate information on chosen environmental projects. Specifically they were interviewed on the variables (ex. nutrition, health etc.) they focus on, when they cover an environmental story like the school gardens one, as well as what means (interviews, filming, etc.) they employ, what educational competency (primary/secondary education, etc.) they assume their audience has, and their preferred mode (TV, radio, etc.) of delivery. Subsequently, there were some questions regarding journalists' prior work on environmental issues and specifically for school gardens. Of interest was, if they had ever been proposed to cover a school program, which had to do with the environment or nutrition/health, and if they, themselves, as students recall to have ever been involved in such educational programs. Finally, they were asked for their personal points of view and suggestions as to what should be included in the environmental programs at schools.

\section{Results}

5.1 Demographic/Social Aspects of the Respondents

Out of the journalists' sample that was interviewed $64 \%$ of participants were women. With regard to the age groups of 
the respondents, $64 \%$ belonged to ages 18 to $25,14 \%$ between 36 to 45 years of age and $21 \%$ was 45 years of age and over. As to the marital status of participants in the survey, $71 \%$ of them were single, $21 \%$ were married and $7 \%$ were divorced._As far as the respondents' level of studies, a large proportion of them were graduates of Media related majors. More specifically, $43 \%$ was studying or had graduated from Communications and Media studies of the National and Kapodistrian University of Athens, $14 \%$ had studied at a foreign University, $21 \%$ had attended private journalism schools. In total a $29 \%$ had a B.A. in Journalism.

With regard to their employment, most of the participants noted that they had worked in more than one Media outlets (TV, radio, etc.). In particular, 36\% had worked at least in one TV channel, $21 \%$ had worked in a radio station, $36 \%$ had worked in printed media and $29 \%$ had worked in online news' websites. Also $14 \%$ of participants stated that they have cooperated with departments of media of various private colleges. A total of $36 \%$ had worked in two or more media outlets. With regard to their current professional status, $14 \%$ was employed in TV, $14 \%$ was working in radio, $21 \%$ was employed in printed media, $21 \%$ in web media website, $14 \%$ was employed in some capacity as a journalist, while $14 \%$ did not have a steady job. With regard to the years they had practiced the profession of journalism, 64\% was occupied from 1 up to 4 years, $29 \%$ from 20 up to 30 years and $7 \%$ was practicing this profession for over 38 years.

\subsection{General Questions on Environmental Education and About School Gardens}

Questions were assigned to the participants focusing on the topics of environmental education and school gardens. In particular, as to what they knew of the existence of school gardens, the results were as follows: $14 \%$ knew enough, $21 \%$ knew very little, while $64 \%$ knew nothing about school gardens. As to what they knew in general for environmental education, the results are as follows: $50 \%$ knew enough and had an integrated view on the matter, $43 \%$ had little information while $7 \%$ did not know about this subject. Then, questions were asked on the opinion the respondents had about what school gardens promote, in the case that they knew about their existence, otherwise, what they suspected that school gardens could promote. A total of $14 \%$, replied to the "improved relation of humans with nature and the rest, $86 \%$, who had little to no knowledge of school gardens, replied "to the promotion of environmental behavior", "increased awareness of the environment", and "improve the environment and thus promote quality of human life".

Related to participants' knowledge on First Lady's Michelle Obama's school gardens' movement, 7\% knew enough, $14 \%$ knew little, while $79 \%$ knew nothing about this issue. As to whether they were aware of Greek school gardens, 93\% was not aware even that they existed, while $7 \%$ knew a few things about them. Also, as to whether they knew about environmental actions carried out in Greek schools, the $71 \%$ knew of several of those actions, such as tree planting, forestation, etc., $14 \%$ had very little information, while the remaining $14 \%$ was not aware of something.

On the question about what the participants knew about media's contribution in reference to the school gardens, $14 \%$ had a comprehensive view, $29 \%$ had little knowledge and the prevailing view was that the media should be more involved in this issue, while $57 \%$ did not know about this issue. In the case of the contribution made by the Greek media, as to the school gardens, the results were as follows: 36\% knew enough about this issue, 29\% knew little with the view that the Greek media should be more involved in this issue and the remaining $36 \%$ did not know about this issue.

With regards to the how a school environmental project could be promoted in the Greek media, there were the following points of view: Promoting it through special programs and advertising spots in various forms of media, such as TV, radio, etc., was proposed by $93 \%$ of the participants, while a 29\% suggested organizing debates or campaigns. One respondent stressed that we must first of all change the mentality of the media, in order to be able to support the promotion of environmental projects that take place at schools. As to why the media should promote an environmental project, $36 \%$ of participants based their response to the need for promotion of environmental awareness and environmental interest, $21 \%$ focused on the increase of environmental sensitivity and $29 \%$ based their responses on the environmental influence for public action. Some other points of view had to do with the positive effects on society and economy.

When the participants were questioned which would have been their preferred topic to concentrate on, in case they were assigned to cover school gardens, the results were the following: 


\title{
Important Issues
}

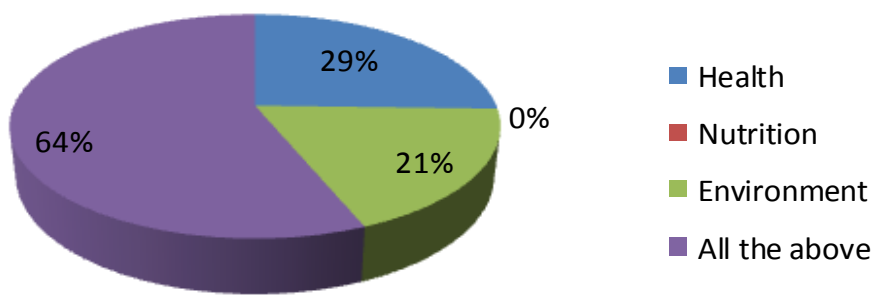

In regards to ways journalists could employ, when presenting school gardens, the replies were as follows:

\section{Means of Presentation}
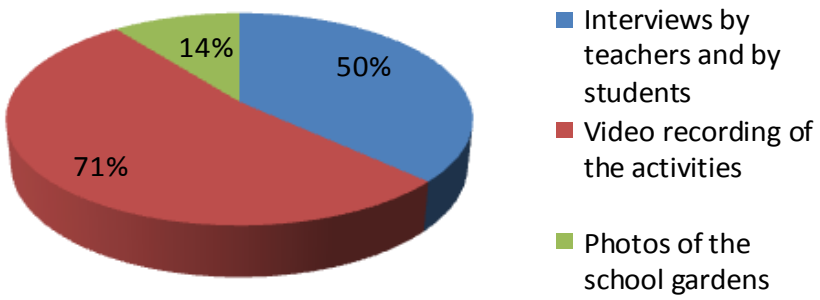

Related to the level of knowledge competency, when covering an environmental issue, they responded as follows:

\section{Level of Education}

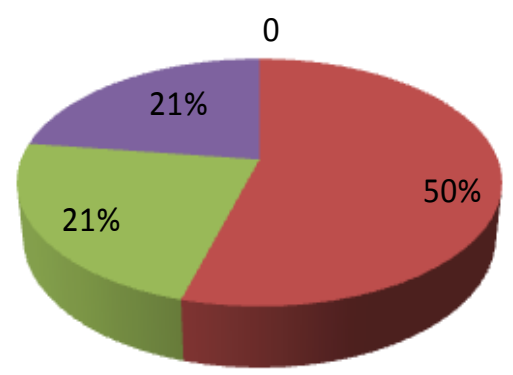

- Primary Education

- Secondary Education

- Higher Education

All levels of education

As regards to what means (TV, radio, press, internet) is considered more appropriate for the dissemination of this environmental project, the responses were as follows:

\section{Appropriate Means}

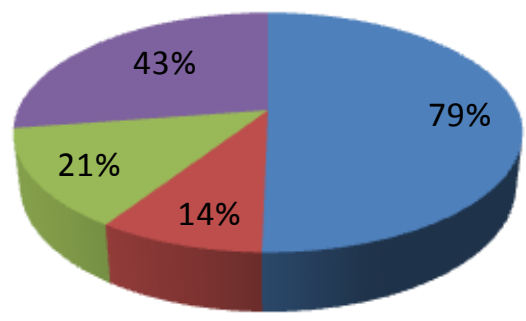

\author{
Television \\ Radio \\ Press \\ Internet
}

It should be noted that $29 \%$ of participants chose more than one instrument as appropriate for the dissemination of environmental work. Then, the respondents were asked if up to now they have covered in the media a health or nutritional program or a topic with environmental interest, which relates to a school and $93 \%$ responded negatively. The next question focused on the journalists' participation on a school environmental program when they were students, and 
$50 \%$ responded positively to this question. Then, the participants responded to what would be their advice, if they could be given the opportunity to contribute on an environmental education project. There was a large variety in terms of responses: $36 \%$ proposed an increase in student activities (trips, tree planting, forestation, group games that relate to the environment, etc.), $43 \%$ believed that it was important to publicize environmental school projects. Emphasizing to students the importance of taking environmental action, participating in environmental social networks, having students acting as environmental reporters were some other ideas that arose. Finally, in what could be included in a school program with regards to the environment, the answers were as follows: specific environmental and environmental education courses being added to the curriculum and enhanced environmental activities were supported by $29 \%$ of respondents and $57 \%$ of them emphasized improved environmental training of teachers.

\section{Conclusions}

Several deficiencies in participants' environmental knowledge were detected in the participants, which happen to work in the Greek media. Their comprehension as far as the school gardens was ambiguous although, worldwide, lots of media attention has been given. In fact $64 \%$ of the respondents did not even know school gardens' existence. This shows that there is a need for direct communication between those working in the Greek media and Environmental Educators. Media happen to be on the front line of informal education strategies and if they invest on environmental education issues the results as far as promotion of responsible environmental behavior would be amazing.

Another interesting point was their lack of knowledge to Michelle Obama's work in USA, which has received tremendous publicity because of her efforts to reduce children's obesity through support of school gardens. Having a $79 \%$ of participants never having heard of her work it kind of puzzles environmental education community on how much journalists even keep up with international environmental movements and if these accomplishments are disseminated to Greeks. Almost all respondents had no idea if school gardens exist in Greek schools, which luckily is in contradiction with the fact that many of them (86\%) knew in general of environmental actions organized by schools and outside of the school area, such as tree planting, forestation, etc. Also, unknown to a sufficiently large proportion of respondents (57\%), was the contribution of the worldwide media as to the school gardens.

Most participating journalists felt that environmental reportage is the best way to disseminate environmental information and half of them believe that through these media efforts responsible environmental behavior can be promoted. Still, the best way (71\%) for the presentation of a school environmental project was considered to be the filming and promoting of the activities carried out in schools, and the most appropriate media means (71\%) was considered to be the TV. An alarming percent (93\%) of interviewed journalists had never been asked to cover a school environmental project, which demonstrates the low interest for covering such issues. Encouraging was the notion that half of them had themselves as students participated in an environmental program of their school and they therefore had appreciated the related benefits on environmental sensitivity.

Finally, when they were asked for their advice as to what should be included in a school environmental program, the opinion that prevailed was emphasis on building skills for environmentally active citizens, which is not the case to a large extent in Greek schools. Thus, it can be concluded that the Greek society will have to take further actions with regard to environmental issues. It would be good to take into account the examples given from other countries, not only those relating to the activities which include environmental education in schools, but also the activities carried out by the citizens, such as the gardens in neighborhoods, etc. In this way, we will be able to understand fully the benefits that can be obtained from the care and from contact with nature, because the environment is the "home" of every human being. The view and the greater involvement of the Greek media with these issues would certainly, create large-scale awareness and more incentives for people to take action, as is done in other countries around the world.

Taking into account what has been said about how the environment is perceived in and outside the school system worldwide, as well as how much attention has been shown from the foreign media on this issue, in comparison with the results obtained from this research, which relates to what is happening in Greece, easily leads to the conclusion that there should be more support in the environmental education and communication field. School gardens are an initiative which should become part of as many Greek schools infrastructure as possible. Greek media can definitely play a pivotal role in the promotion of responsible environmental behavior, and school gardens movement present an excellent opportunity. The environment should be a part of everyday life and human beings have an obligation to protect it in order to enjoy all of the benefits that the environment can ensure. Incorporating gardens at schools certainly leads to the achievement of particularly important environmental goals. Students, in direct cooperation with the teachers, develop unique skills and abilities for their wellbeing and citizenship responsibilities. They acquire knowledge through group and personal projects on how to resolve potential issues, like people affecting the environmental quality, agricultural procedures and availability of food resources, water usage, etc. Finally, it is certain that their personal values and beliefs and understanding would be positively affected. 
Our youth is the most precious asset. Supporting their environmental conscious, would later on enable them to actively participate in the environmental decision making. When environmentally educated young individuals grow up, as residents they would willingly participate in a societal movement, especially when they observe that their way of life is endangered (Skanavis et al. 2005). Social acceptance is based on variables that deal with geography, visual impact, ownership, local economy, information, and participation (Skanavis et al. 2014). Media are in the front-line of environmental communication and the promotion of school gardens' issue presents a wonderful opportunity for responsible environmental behavior. The main goal of suitable environmental communication is that citizens build a conscientious environmental approach. Environmental consciousness is a significant factor in the formation of a responsible environmental behavior. The mass media can fortify the extent of environmental consciousness of the whole community via release of environmental information (Skanavis and Sakellari 2007), like the school gardens, which is the focus of this paper.

\section{References}

Alaimo, K., Packnett, E., Miles, R.A., \& Kruger, D.J. (2008). Fruit and vegetable intake among urban community gardeners. Journal of Nutrition Education and Behavior, 40, 94-101. http://dx.doi.org/10.1016/j.jneb.2006.12.003

Ardoin, N. (2006). Toward an interdisciplinary understanding of place: Lessons for environmental education'. Canadian Journal of Environmental Education, 11 (1), 112-26.

Bandura, A. (1997) Self-efficacy: The exercise of control, WH Freeman and company, New York.

Barratt Hacking, E., Barratt, R., \& Scott, W. (2007). Engaging children: research issues around participation and environmental learning. Environmental Education Research, 13, 529-544. http://dx.doi.org/10.1080/13504620701600271

Bartlett, C., Sterne, J., \& Egger, M. (2002). What is newsworthy? Longitudinal study of the reporting of medical research in two British newspapers. British Medical Journal, 325, 81-84. http://dx.doi.org/10.1136/bmj.325.7355.81

Bassett, T.J. (1979). Vacant lot cultivation: community gardening in America, 1893-1978. Unpublished Master's Thesis, University of California, Berkeley.

Basu, A. J., \& Hogard, E. (2008). Fit for public consumption? An exploratory study of the reporting of nutrition research in UK tabloids with regard to its accuracy, and a preliminary investigation of public attitudes towards it. Public Health Nutrition, 11 (11), 1124-1131. http://dx.doi.org/10.1017/S1368980007001565

Bell, R.A, Cassady, D., Culp, J., \& Alcalay, R. (2009). Frequency and types of foods advertised on Saturday morning and weekday afternoon English- and Spanish-language American television programs. Journal of Nutrition Education and Behavior, 41(6), 406-413. http://dx.doi.org/10.1016/j.jneb.2008.05.008

Bell, R.A., Berger, C.R., Cassady, D., \& Townsend, M.S. (2005). Portrayals of food practices and exercise behavior in popular American films. Journal of Nutrition Education and Behavior, 37, $27-32$. http://dx.doi.org/10.1016/S1499-4046(06)60256-X

Blair, D. (2009). The child in the garden: an evaluative review of the benefits of school gardening. The Journal of Environmental Education, 40(2), 15-38. http://dx.doi.org/10.3200/JOEE.40.2.15-38

Borra, S.T., Earl, R., \& Hogan, E.H. (1998). Paucity of nutrition and food safety 'news you can use' reveals opportunity for dietetics practitioners. Journal of the American Dietetic Association, 98, 190-193. http://dx.doi.org/10.1016/S0002-8223(98)00047-9

Brink, L., \&Yoast, B. (2004). Transforming inner-city school grounds: Lessons from learning landscapes. Children, Youth and Environments, 12, 208-232.

Brown, B.B., \& Perkins, D. (1992). Disruptions in place attachment', in Altman, I. \& Low, S. (Eds.). Place Attachment, Plenum Press, New York, 279-304. http://dx.doi.org/10.1007/978-1-4684-8753-4_13

Brundtland, G.H. (1987). Our common future, The report of the World Commission on the Environment and Development, Oxford University Press, Oxford.

Caburnay, C.A., Kreuter, M.W., Luke, D.A., Logan, R.A., Jacobsen, H.A., Reddy, V.C, Vempaty, Anitha, R., \& Zayed, Hythem, R. (2003). The news on health behavior: Coverage of diet, activity, and tobacco in local newspapers. Health Education \& Behavior, 30 (6), 709-722. http://dx.doi.org/10.1177/1090198103255456

Calloway, C., Jorgensen, C. M., Saraiya, M., \& Tsui, J. (2006). A content analysis of news coverage of the HPV vaccine by US newspapers, January 2002-June 2005. Journal of Women's Health, 15(7), 803-809. http://dx.doi.org/10.1089/jwh.2006.15.803 
Campos, P., Saguy, A., Ernsberger, P., Oliver, E., \& Gaesser, G. (2006). The epidemiology of overweight and obesity: Public health crisis or moral panic?. International Journal of Epidemiology, 35, 55-60. http://dx.doi.org/10.1093/ije/dyi254

Chapin, F.S., Power, M.E., Pickett, S.T.A., Freitag, A., Reynolds, J.A., Jackson, R.B., Lodge, D.M., Duke, C., Collins, S.L., Power, A.G., \& Bartuska, A. (2011). Earth Stewardship: science for action to sustain the human-earth system. Ecosphere, 2(89). http://dx.doi.org/10.1890/ES11-00166.1

Chawla, L. (1994). Gardening as an initiation into environmental action. American Horticulturist, July, 6-7.

Chawla, L. (1998). Significant life experiences revisited: A review of research on sources of environmental sensitivity. The Journal of Environmental Education, 29 (3), 369-383. http://dx.doi.org/10.1080/00958969809599114

Chawla, L. (2007). Childhood experiences associated with care for the natural world: a theoretical framework for empirical results. Children, Youth and Environments, 17 (4), 144-170.

Contento, Isobel R. (2007). Nutrition Education: Linking Research, Theory and Practice, Jones and Bartlett Publishers, Inc. Sudbury, MA.

Cooksey, K., Kohlmeier, M., Plaisted, C., Adams, K., \& Zeisel, S. H. (2000). Getting nutrition education into medical schools: a computer-based approach. Am. J. Clin. Nutr., 72(3), 868-876.

Corson, C. (2003). Grounds for learning: Hope for America's derelict schoolyards. http://www.cherylcorson.com/publications.html (Accessed 23 August 2008).

CWS, Ltd. (2000). Blackmail - The first in a series of inquiries into consumer concerns about the ethics of modern food production and advertising, Co-operative Group (CWS) Ltd, Manchester.

D’Abundo, M.L., \& Carden, A.M. (2008). "Growing wellness": The possibility of promoting collective wellness through community garden education programs. Journal of the Community Development Society, 39, 83-94. http://dx.doi.org/10.1080/15575330809489660

Demas, S. (1979). 'School gardens and environmental education'. Nature Study, 32 (3), 3-5.

Dyment, J.E., \& Bell, A.C. (2007). Active by design: promoting physical activity through school ground greening. Children's Geographies, 5, 463-477. http://dx.doi.org/10.1080/14733280701631965

Faber Taylor, A., Kuo, F.E., \& Sullivan, W.C. (2001). Views of nature and self- discipline: evidence from inner city children. Journal of Environmental Psychology, 21, 1-15.

Faddegon, P.A. (2005). The kids growing food school gardening program: Agricultural literacy and other educational outcomes. Doctoral dissertation, Cornell University, Ithaca, NY.

Finch, K. (2004). Extinction of experience: A challenge to nature centers? (Or, how do you make a conservationist?). Directions: The Journal of the Association of Nature Center Administrators, Special Issue, 1-7.

Firey, W. (1945). Sentiment and symbolism as ecological variables. American Sociological Review, 10, 140-148. http://dx.doi.org/10.2307/2085629

Francis, M. (1995). Childhood's garden: memory and meaning of gardens. Children's Environments, 12(2), 1-16 http://www.colorado.edu/journals/cye (Accessed 12 October 2009).

Gantz, W., Schwartz, N., Angelini, J.R., \& Rideout, V. (2007). Food for thought: Television food advertising to children in the United States. Kaiser Family Foundation, http://www.kff.org/entmedia/upload/7618ES.pdf (Accessed 15 May 2011).

Gerbner, G., Gross, L., Morgan, M., \& Signorielli, N. (1981). Health and medicine on television. New England Journal of Medicine, 305, 900-904. http://dx.doi.org/10.1056/NEJM198110083051530

Goldberg, J. P. (1992). Nutrition and health communication: The message and the media over half a century. Nutrition Reviews, 50 (3), 71-77. http://dx.doi.org/10.1111/j.1753-4887.1992.tb01272.x

Gore, S.A., Foster, J.A., DiLillo, V.G., Kirk, K., \& Smith West, D. (2003). Television viewing and snacking. Eating Behaviors, 4 (4), 399-405. http://dx.doi.org/10.1016/S1471-0153(03)00053-9

Graham, H., Beall, D.L., Lussier, M., McLaughlin, P., \& Zidenberg-Cherr, S. (2005). Use of school gardens in academic instruction. Journal of Nutrition Education Behavior, 37 (3), 147-151. http://dx.doi.org/10.1016/S1499-4046(06)60269-8

Gross, H., Lane, N. (2007). Landscapes of the lifespan: exploring accounts of own gardens and gardening. Journal of Environmental Psychology, 27, 225-241. http://dx.doi.org/10.1016/j.jenvp.2007.04.003 
Halpenny, E.A. (2010). Pro-environmental behaviors and park visitors: the effect of place attachment. Journal of Environmental Psychology, 30, 409-421. http://dx.doi.org/10.1016/j.jenvp.2010.04.006

Hart, R. (1994). Fostering earth stewardship. American Horticulturist, 5-6 July.

Hastings, N.B, \& Tracey, M.W. (2005). Does media affect learning: Where are we now?. TechTrends Linking Research and Practice to Improve Learning, 49, 28-30.

Heerwagen, J.H., \& Orians, G.H. (2002). The ecological world of children', in Kahn, P.H. and Kellert, S.R. (Eds.). Children and Nature. Psychological, Sosiocultural, and Evolutionary Investigations, The MIT Press, Cambridge, MA, 29-63.

Heim, S., Stang, J., \& Ireland, M. (2009). A garden pilot project enhances fruit and vegetable consumption among children. Journal of the American Dietetic Association, 109, 1220-1226. http://dx.doi.org/10.1016/j.jada.2009.04.009

Heneghan, M.K., Hazan, C., Halpern, A.C., \& Oliveria, S.A. (2007). 'Skin cancer coverage in a national newspaper: A teachable moment'. Journal of Cancer Education, 22 (2), 99-104. http://dx.doi.org/10.1007/BF03174356

Hermann, J.R., Parker, S.P., Brown, B.J., Siewe, Y.J., Denney, B.A., \& Walker, S.J. (2006). After-school gardening improved children's reported vegetable intake and physical activity. Journal of Nutrition and Education Behavior, 38, 201-202. http://dx.doi.org/10.1016/j.jneb.2006.02.002

Hertzler, A.A., \& Grun, I. (1990). Potential nutrition messages in magazines read by college students. Adolescence, 25.

Holder, H.D., \& Treno, A.J. (1997). Media advocacy in community prevention: News as a means to advance policy change. Addiction, 92 (2), 189-199. http://dx.doi.org/10.1046/j.1360-0443.92.6s1.3.x

Jacobs, M.H., \& Buijs, A.E. (2011). Understanding stakeholders' attitudes toward water management interventions: Role of place meanings, Water Resources Research 47, http://dx.doi.org/10.1029/2009WR008366

Jeffery, R.W., \& French, S.A. (1998). Epidemic obesity in the United States: are fast foods and television viewing contributing?. American Journal of Public Health, 88 (2), 277-280. http://dx.doi.org/10.2105/AJPH.88.2.277

Kaufman, L. (1980). Prime Time Nutrition'. Journal of Communication, 30 (3), 37-46. http://dx.doi.org/10.1111/j.1460-2466.1980.tb01989.x

Keenan, D. P., AbuSabha, R., \& Robinson, N. G. (2001). Content analysis of media coverage of the 1995 dietary guidelines for Americans. Journal of Extension, 39(5). http://www.joe.org/joe/2001october/rb5.php (Accessed 25 September 2008).

Kellert, S.R. (2002). Experiencing nature: affective, cognitive and evaluative development in children in Kahn. P.H. and Kellert, S.R. (Eds.). Children and Nature.

Kennedy, G.E., \& Bero, L.A. (1999). Print media coverage off research on passive smoking. Tobacco Control, 8(3), 254-260. http://dx.doi.org/10.1136/tc.8.3.254

Kong, L. (2000). Nature's dangers, nature's pleasures: urban children and the natural world, in Holloway, S.L. and Valentine G. (Eds.), Children's geographies: playing, living, learning, Routledge, London, 257-271.

Kong, L., \& Yeoh, B.S.A. (1995). The meanings and making of place: Exploring history, community and identity, in Yeoh, B.S.A. and Kong, L. (Eds.), Portraits of places: History community and identity in Singapore, Times Editions, Singapore, 12-23.

Krasny, M., \& Tidball, K. (2009). Community Gardens as Contexts for Science, Stewardship, and Civic Action Learning, Cities and the environment, 2(1), 1-18.

Krasny, M.E., \& Tidball, K.G. (2009). Applying a resilience systems framework to urban environmental education. Environmental Education Research, 15, 465-482. http://dx.doi.org/10.1080/13504620903003290

Kuo, F.E., \& Faber Taylor, A. (2004). A potential natural treatment for Attention- Deficit/Hyperactivity Disorder: evidence from a national study. American Journal of Public Health, 94, 1580-1586. http://dx.doi.org/10.2105/AJPH.94.9.1580

Kuo, F.E., \& Sullivan, W.C. (1998). Fertile ground for community: inner-city neighborhood common spaces. American Journal of Community Psychology, 26(6), 823-851. http://dx.doi.org/10.1023/A:1022294028903

Kuribayashi, A., Roberts, M.C., \& Johnson, R.J. (2001). Actual nutritional information of products advertised to children and adults on Saturday children's health care. Child Health Care, 30(4), 309-322. http://dx.doi.org/10.1207/S15326888CHC3004_05 
Kweon, B.S., \& Sullivan, W.C. et al. (1998). Green common spaces and the social integration of inner-city older adults. Environment and Behavior, 30(6), 832-848. http://dx.doi.org/10.1177/001391659803000605

Lawson, L. J. (2005). City bountiful: A century of community gardening in America, University of California Press, Berkeley, 21.

Leopold, A. (1949). A Sand County almanac and sketches here and there, Oxford University Press, New York, USA.

Louv, R. (2005). Last child in the woods: saving our children from nature-deficit disorder, Algonquin Books, Chapel Hill, NC.

Lynch, K. (1960). The image of the city, MIT Press, Cambridge, Massachusetts, USA.

McNeal, J.U. (1992). The little shoppers. American Demographics, 14(2), 48-52.

Mergen, B. (2003). Review essay: Children and nature in history. Environmental History, 8, 643-669. http://dx.doi.org/10.2307/3985888

Miller, M.A. (2005). An exploration of children's gardens: reported benefits, recommended elements, and preferred visitor autonomy. Unpublished $\mathrm{PhD}$ thesis, The Ohio State University.

Miller, M.A. (2007). Editorial - A rose by any other name: environmental education through gardening. Applied Environmental Education and Communication, 6, 15-17. http://dx.doi.org/10.1080/15330150701385769

Montessori, M. (1964) The Montessori Method, Shocken Books, UK.

Moore, R.C. (1995). Children gardening: first steps towards a sustainable future. Children's Environments Quarterly, $12,222-232$.

Nabhan, G.P., \& Trimble, S. (1994). The geography of childhood: Why children need wild spaces, Beacon Press, Boston.

Neuendorf, A. (2002). The content analysis guidebook, Sage Publications, Thousand Oaks, CA, 205.

O'Hara, S. K., \& Smith, K. C. (2007). Presentation of eating disorders in the news media: What are the implications for patient diagnosis and treatment?. Patient Education \& Counseling, 68(1), 43-51. http://dx.doi.org/10.1016/j.pec.2007.04.006

Orr, D.W. (2002). Political economy and the ecology of childhood, in Kahn, Jr.P.H. and Kellert, S.R. (Eds.), Children and nature: Psychology, sociocultural and evolutionary investigations, MIT Press Cambridge, MA, 279-303.

Oxman, A. D., Guyatt, G. H., Cook, D.J., Jaeschke, R., Heddle, N., \& Keller, J. (1993). An Index of scientific quality for health reports in The Lay Press. Journal of Clinical Epidemiology, 46(9), 987-1001. http://dx.doi.org/10.1016/0895-4356(93)90166-X

Ozer, E.J. (2007). The effects of school gardens on students and schools: conceptualization and considerations for maximizing healthy development. Health Education \& Behaviour, 34, 846-863. http://dx.doi.org/10.1177/1090198106289002

Parvanta, S.A., Brown, J.D., Shufa, D., Xinshu, Z., \& Zhai, F. (2008). Conference Papers - International Communication Association. Annual Meeting, 1-24.

Passy, R., Morris, M., \& Reed, F. (2010). Impact of School Gardening on Learning Final Report Submitted to the Royal Horticultural Society, National Foundation for Educational Research.

Patterson, R.E., Satia, J.A., Kristal, A.R., Neuhouser, M.L., \& Drewnowski, A. (2001). Is there a consumer backlash against the diet and health message?. Journal of the American Dietetic Association, 101, 37-41. http://dx.doi.org/10.1016/S0002-8223(01)00010-4

Pierce, J.P., \& Gilpin, E.A. (2001). News media coverage of smoking and health is associated with changes in population rates of smoking cessation but not initiation. Tobacco Control, 10(2), 145-153. http://dx.doi.org/10.1136/tc.10.2.145

Rahm, J. (2002). Emergent learning opportunities in an inner-city youth gardening program. Journal of Research in Science Teaching, 39, 164-184. http://dx.doi.org/10.1002/tea.10015

Relph, E. (1976). Place and placelessness, Pion, London, UK.

Robinson, T.N. (1999). Reducing children's television viewing to prevent obesity. J. American Medical Assoc., 282, 1561-1566. http://dx.doi.org/10.1001/jama.282.16.1561

Scannell, L., \& Gifford, R. (2010). The relations between natural and civic place attachment and pro-environmental behavior. Journal of Environmental Psychology, 30, 289-297. http://dx.doi.org/10.1016/j.jenvp.2010.01.010 
Schrieber, P. (1998). Community gardening: Design, technique, and tools, in Simson, S. and Straus, M. (Eds.). Horticulture as therapy: Principles and practice, The Food Products Press/Haworth Press, New York, 377-397.

Skanavis, C., \& Sakellari, M. (2007). Assessment of environmental intention of journalists. Appl Environ Educ Commun, 6(3), 233-240.

Skanavis, C., Giannoulis, C., \& Skanavis, V. (2014). The Significance of the Environmental Communication for the Renewable Energy Governance Scenario: Who Decides for Whom', in Michalena, E. and Hills, J. M. (Eds.), Renewable Energy (RE) Governance: Complexities and Challenges, Lecture Notes in Energy, Chapter: 21, Springer, 351-362.

Skanavis, C., Koumouris, G., \& Petreniti, V. (2005). Public participation mechanisms in environmental disasters. Environ Manag, 35 (6), 821-837. http://dx.doi.org/10.1007/s00267-004-0120-z

Stedman, R.C. (2008). What do we "mean" by place meanings? Implications of place meanings for managers and practitioners', in Kruger, L.E., Hall, T.E. and Stiefel, M.C. (Eds.), Understanding concepts of place in recreation research and management, General technical report PNW-GTR-744. U.S. Department of Agriculture, Forest Service, Pacific Northwest Research Station, Portland, Oregon, USA, 61-81.

Subramaniam, A. (2002, summer) Garden-based learning in basic education: A historical review, Monograph, 1-11 http://fourhcyd.ucdavis.edu/publications/monograph.html (Accessed 3 June 2006).

Taras, H. L., \& Gage, M. (1995). Advertised foods on children's television. Archives of Pediatric and Adolescent Medicine, 149, 649-652. http://dx.doi.org/10.1001/archpedi.1995.02170190059010

Taylor, J. (2000). A garden of their own. American Nurseryman, 191, 78-85.

Thorp, L., \& Townsend, C. (2001, December 12). Agricultural education in an elementary school: An ethnographic study of a school garden. Proceedings of the $28^{\text {th }}$ Annual National Agricultural Education Research Conference in New Orleans, LA, 347-360. http://www.aaaeonline.org/conference_files/758901

Tuan, Y.F. (1977). Space and place: the perspective of experience, University of Minnesota Press, Minneapolis, Minnesota, USA.

U.S. Department of Health and Human Services [USDHHS], Health Resources and Services Administration. (2010) The registered nurse population: Initial findings from the 2008 National Sample Survey of Registered Nurses http://bhpr.hrsa.gov/healthworkforce/rnsurvey/initialfindings2008.pdf (Accessed 7 April 2011).

Vesilind, E.M., \& Jones, M.C. (1998). Gardens or graveyards? Science education reform and school culture. Journal of $\begin{array}{lllll}\text { Research in } & \text { Science }\end{array}$ http://dx.doi.org/10.1002/(SICI)1098-2736(199809)35:7<757::AID-TEA6>3.0.CO;2-K

Wake, S.J. (2007a). Designed for learning: applying 'learning-informed design' for children's gardens. Applied Environmental Education and Communication, 6, 31-38. http://dx.doi.org/10.1080/15330150701318778

Wake, S.J. (2008). In the best interest of the child': juggling the geography of children's gardens (between adult agendas and children's needs). Children's Geographies, 6 (4), 423-435. http://dx.doi.org/10.1080/14733280802338122

Waliczek, T.M., Bradley, R.D., Lineberger, R.D., \& Zajicek, J.M. (2000). Using a web-based survey to research the benefits of children's gardening. HortTechnology, 10, 71-76.

Walker, G.J., \& Chapman., R. (2003). Thinking like a park: the effects of sense of place, perspective taking, and empathy on pro-environmental intentions. Journal of Park and Recreation Administration, 21, 71-86.

Whitmarsh, L., \& O'Neill, S. (2010). Green identity, green living? The role of pro-environmental selfidentity in determining consistency across diverse pro-environmental behaviours. Journal of Environmental Psychology, 30, 305-314. http://dx.doi.org/10.1016/j.jenvp.2010.01.003

Williams, V.H., Aleong, J., Merrow, S.B., \& Morse, E.H. (1980). Teaching nutrition with films. Home Economics Research Journal, 8(4), 261-268. http://dx.doi.org/10.1177/1077727X8000800404

Young, M. (1999a). The relationship between tourist motivations and the interpretation of place meaning. Tourism Geographies, 1(4), 387-405. http://dx.doi.org/10.1080/14616689908721333

\section{(cc) $\mathrm{BY}$}

This work is licensed under a Creative Commons Attribution 3.0 License 